\title{
Attenuation of The Protective Effect of Honey On Alcohol Induced Hepatotoxicity By Kolanut In Male Albino Rats
}

\section{Adeoye Waheed Saka}

Ladoke Akintola University of Technology College of Health Sciences

\section{Busuyi David Kehinde}

Ladoke Akintola University of Technology College of Health Sciences

Adebola Olayemi Akintola ( $\square$ aoakintola@lautech.edu.ng )

Ladoke Akintola University of Technology Faculty of Pure and Applied Science https://orcid.org/00000003-0877-2139

\section{Samuel Seyi Oyekanmi}

Ladoke Akintola University of Technology College of Health Sciences

\section{Ajoke Esther Oyewande}

Ladoke Akintola University of Technology College of Health Sciences

\section{Murphy Dumbiri Ogwumu}

Delta State University

\section{Research}

Keywords: Ethanol, Honey, Kolanut, Hepatotoxicity, ALT, AST

Posted Date: June 29th, 2020

DOl: https://doi.org/10.21203/rs.3.rs-36975/v1

License: (c) (1) This work is licensed under a Creative Commons Attribution 4.0 International License. Read Full License 


\section{Abstract}

Background: The excessive use of alcohol can lead to alcohol liver damage. However, natural compounds such as honey and kolanut have been investigated to have hepatoprotective activities against liver damage.

Objectives: The possible protective effects of aqueous extract of kolanut and honey and the combination of both on alcohol induced hepatotoxicity of male rats were investigated.

Materials and Methods: The rats were randomly divided into five equal groups $(n=6)$. Group A was allowed access to water; Group B received ethanol ( $45 \%$ at $3 \mathrm{~g} / \mathrm{kg}$ ) once for 21 days, Group C, D and E received alcohol an hour before treated with $50 \mathrm{mg} / \mathrm{kg}$ of Cola nitida, $2.5 \mathrm{~g} / \mathrm{kg}$ of honey and combination of both respectively. Histopathological analysis and measurement of serum alanine aminotransferase (ALT), aspartate amino transferase (AST), alkaline phosphatase (ALP), malondialdehyde (MDA) and catalase (CAT).

Results: Administration of ethanol $(45 \%)$ at $3 \mathrm{~g} / \mathrm{kg}$ to rats resulted in significant $(P<0.05)$ increase in the activities of hepatic markers enzymes (ALT, AST, ALP) as compared with control. Pretreatment of rats with kolanut $(50 \mathrm{mg} / \mathrm{kg})$ and honey $(2.5 \mathrm{~g} / \mathrm{kg})$ separately caused significant reduction in ALT, AST and ALP activities while pretreatment with combination of both was not better than the decrease observed when pretreated separately as compared to alcohol-induced group. Conversely, the results of oxidative stress and histological findings took a different pattern in all the pretreated groups.

Conclusion: The result showed that the combination of honey and kolanut does not work synergistically in alcohol-induced hepatic damage.

\section{Background}

Excessive alcohol consumption causes a number of health challenges with socio-economic consequences (Souza et al., 2017). Alcohol has a pleasant subjective effects (Karlsson and Roman, 2016), which reinforce its consumption and play a pivotal role in the onset of alcohol-related diseases (Hendler et al., 2013). Alcoholic liver disease is one of the most common causes of chronic liver disease worldwide. Individuals who perceive the drug as more rewarding and less aversive may be at higher risk for alcohol-related diseases (Schuckit et al., 2004; Hendler et al., 2013). Depending on dose and time, alcohol produces both stimulatory and depressant effects on behavior subjects (Brabant et al., 2014; Karlsson and Roman, 2016). The negative effects of alcohol consumption depend on the amount consumed, time of exposure and drinking pattern (WHO, 2014; Souza et al., 2017). Ethanol is the major constituent of alcoholic beverages and it is the chemical responsible for alcohol addiction and alcoholism (Garcia et al., 2015). Ethanol acts as a toxic substance to vital organs of the body including liver, brain, kidney and heart (Lieber, 1988; Garcia et al., 2015). 
The liver is highly susceptible to injurious attack by offending xenobiotics as it plays a pivotal role in the removal of substances from portal circulation (Bodakhe and Ram, 2007). Moreover, the liver sustains the greatest amount of organ damage from excessive alcohol use, as the metabolism of alcohol occurs primarily in the organ (Lieber, 2004). The metabolism of ethanol results in oxidative stress. Ethanol disrupts the delicate balance between the pro- and anti-oxidant system of the body, culminating in oxidative stress (Lieber, 1988; Garcia et al., 2015). Ethanol induces the generation of reactive oxygen species (ROS) and reactive nitrogen species (RNS) and in their high levels may cause necrosis of liver cells (Hou et al., 2010; Shi et al., 2017)

The use of natural products for medicinal purposes by diverse peoples and cultures of the world is as old as mankind (Christophersen et al., 1991; Van Wyk and Gericke, 2000; Dewole et al., 2013; DahNouvlessounon et al., 2015). Honey is one of the oldest known natural products with medicinal properties. Honey is widely accepted to be beneficial to health and it has been traditionally used both in the Middle East and Africa as a curative substance for a number of human illnesses including signs and symptoms of Upper Respiratory Tract Infections (URTIs), especially coughing (Shadkam et al., 2010; Raeessi et al., 2014). Contemporary scientific researchers have affirmed the multiple functions of honey. Honey has antimicrobial, cardio-protective and gastric protective properties (Gharzouli et al., 2002; Nasuti et al., 2006; Alvarez-Suarez et al., 2010). Honey improves blood profiles, heals wounds and ameliorates oxidative stress and risk factors of metabolic and cardiovascular diseases (Molan, 1999; Chepulis, 2007; Ajibola et al., 2012). The medicinal properties of honey has been linked with its chemical constituents including its richness in monosaccharides (fructose and glucose) and antioxidants such as phenols, ascorbic acid and flavonoids (Raeessi et al., 2014; Garciaa et al., 2015; Shi et al., 2015; Zhao et al., 2017). Besides, honey is made up of colloidal suspended particles in form of protein materials, enzymes (invertase, catalase and diastase), wax particles, pollen grains, silica, and other extraneous matter (Root et al., 2005). Kolanut (Cola nitida) is among the highly used medicinal plants in Africa (DahNouvlessounon et al., 2015). It is an essential commodity in social and ceremonial events of Africans (Dewole et al., 2013; Dah-Nouvlessounon et al., 2015). Kolanut is commonly used by many people as a stimulant; it prevents sleep, thirst, and hunger and acts as an antidepressant (Lowor et al., 2010; Dewole et al., 2013; Muhammad and Fatima, 2014). Kolanut is applied industrially in the manufacture of dyes, wines, candies, drugs and soft drinks such as pepsi cola and coca cola (Javies, 2002; Ayebe et al., 2012; Dah-Nouvlessounon et al., 2015). Kolanut (Cola nitida) is made up of two percent caffeine and contains a wide variety of complex secondary plant metabolites and antioxidants including phytochemicals like phenols and flavonoids (Javies, 2002; Ayebe et al., 2012; Dah-Nouvlessounon et al., 2015). Both honey and kolanut have separately been found to be antimicrobial agents and confer protection against free radical-induced damage (Alvarez-Suarez et al., 2010; Dah-Nouvlessounon et al., 2015). Whereas honey has been found to produce anti-intoxication effects and prevent alcohol-induced liver damage (Gharzouli et al., 2002; Garciaa et al., 2015; Zhao et al., 2017), no previous study has been carried out to ascertain the effect of Cola nitida on alcohol-induced liver damage. More so, there are no previous reports on the treatment of alcohol induced liver damage by combining kolanut and honey. Therefore, this present study 
was designed to evaluate the effects honey and Cola nitida will produce separately on alcohol-induced liver damage as well as the treatment impact of combining both on alcohol induced liver damage.

\section{Materials And Methods}

\section{Plant Material}

Fresh specimens of Kolanut (Voucher no: LHO 545) were bought from Ogbomoso, Nigeria market and authenticated in the taxonomy unit of the Department of Pure and Applied Biology, Ladoke Akintola University of Technology, Ogbomoso, Oyo State. Ethanol (96\%) was purchased from Osogbo and Honey was purchased from Oluwadamilare agro farms, ljebu ode.

\section{Preparation of the Aqueous Extract of Cola nitida (AECON).}

Fresh specimens of Cola nitida were washed and cut into smaller bits and air-dried for four weeks, the dried specimens were pulverized using laboratory mortar and pestle. A $350 \mathrm{~g}$ portion of the pulverized specimens was macerated and extracted with distilled water $(1: 2 \mathrm{w} / \mathrm{v})$ for 72 hours at room temperature $\left(26-28^{\circ} \mathrm{C}\right)$. The resulting solution was then filtered using a wire-gauze and a sieve with tiny pores $(0.25$ $\mathrm{mm}$ ). The distilled water was later evaporated using steam bath to give a percentage yield of $12.4 \%$ of the extract.

Ten grams of the aqueous extract of Cola nitida (AECON) was dissolved in $200 \mathrm{ml}$ of distilled water to give a concentration of $0.5 \mathrm{~g} / \mathrm{ml}$.

\section{Animals}

Adult male albino rats weighing between $150 \mathrm{~g}$ and $200 \mathrm{~g}$ were bought from the animal house of Physiology Department, Ladoke Akintola University of Technology, Ogbomoso under standard laboratory conditions with a 12 hours daylight cycle. They were acclimatized and had free access to feed and water; before the commencement of the experiments. All experiments were carried out in compliance with the recommendations of Helsinki's declaration on guiding principles on care and use of animals.

\section{Experimental Design}

Thirty animals were randomly divided into five groups with each group consisting of six rats and were subjected to the following oral treatments once daily for 21 days: The rats in the control group (group A) received food and water only; rats in group B were orally administered with ethanol (45\%) at $3 \mathrm{~g} / \mathrm{kg}$ dose; rats in group $C$ were administered orally with aqueous extract of Cola nitida at $50 \mathrm{mg} / \mathrm{kg}$ dose and ethanol $(45 \%)$ at $3 \mathrm{~g} / \mathrm{kg}$ after 1 hour; rats in group D were administered orally with honey at $2.5 \mathrm{~g} / \mathrm{kg}$ dose and ethanol (45\%) at $3 \mathrm{~g} / \mathrm{kg}$ after 1 hour; rats in group E were administered orally with both aqueous extract of Cola nitida $(50 \mathrm{mg} / \mathrm{kg}$ ) and honey $(2.5 \mathrm{~g} / \mathrm{kg})$ and ethanol $(45 \%)$ at $3 \mathrm{~g} / \mathrm{kg}$ after 1 hour. Twelve hours after the administration of the last ethanol dose, the rats were weighed and cervical dislocation was carried out. 


\section{Collection of Blood Sample and Preparation of Liver Homogenate}

Blood samples were collected from the heart and centrifuged at $1,500 \mathrm{rpm}$ at $4^{0} \mathrm{C}$ for 10 minutes to obtain serum. The abdominal cavity of each rat was opened up through a midline abdominal incision to expose the liver. The liver was excised and weighed; the liver was weighed with an electronic analytical and precision balance. The liver of each animal was fixed in $10 \%$ formol-saline for histological examination.

\section{Serum Biochemical Assay}

Serum alanine aminotransferase (ALT) and aspartate aminotransferase (AST) activities were determined by the colorimetric method of Reitman and Frankel as described by Ochei and Kolhatkar (2005). Plasma alkaline phosphatase (ALP) was determined by the method of Kind and Kings (1954).

\section{Estimation of CAT and MDA in the liver}

Catalase (CAT) activity was measured according to the method of (Aebi, 1983). Lipid peroxidation was determined by the method of Varshney and Kale (1990). Estimation of lipid peroxidation was based on the reaction of malondialdehyde (MDA) with thiobarbituric acid (TBA) forming an MDA-TBAR adduct that absorbed light strongly at 532nm.

\section{Histological Study}

The liver tissues were allowed to fix in $10 \%$ formal saline for 48 hours. The tissues were grossed and cut into smaller pieces of $3 \mathrm{~mm}$ thick in pre-labeled tissue cassette. They were processed using automatic tissue processor (LEICA TP1020) where they passed through various reagents including alcohol (of various concentrations starting from $70 \%, 80 \%, 90 \%, 95 \%$, and two $100 \%$ or absolute alcohol) for dehydration, two changes of xylene and three changes of molten paraffin wax set at 65 degree centigrade. The processing time was 12 hours. The tissues were then embedded in paraffin wax by burying the tissues in a metal mold containing molten paraffin wax and were allowed to form paraffin blocks, ready for microtomy. The tissues were sectioned at 4 microns using rotary microtome (LEICA RT2115) and the sections were floated on hot water bath to attach the sections to pre-labeled slides. The sections were dried on hot plate and then stained using haematoxylin and eosin staining technique. After clearance, the tissues were oven-dried and photomicrographs were taken with the aid of Japan Victor Company (JVC) colored video digital camera (JVC, Japan) which was mounted on an Olympus light microscope (Olympus UK Limited, United Kingdom).

\section{Statistical analysis}

Data were expressed using Graph pad prism 6. Data were expressed as Mean \pm Standard error of mean (Mean \pm S.E.M). Values were compared using one-way analysis of variance (ANOVA) followed by student t-test. $P$ - Values less than 0.05 were taken to be statistically significant and insignificant at $P>0.05$ 


\section{Results}

Table 1 and Fig. 1 showed that the administration of ethanol (45\%) at $3 \mathrm{~g} / \mathrm{kg}$ dosage significantly increased the activities of alanine amino transferase (ALT), aspartate amino transferase (AST) and alkaline phosphatase (ALP) when compared with the control (group A) at $\mathrm{P} \otimes 0.05$ but pretreatment with $50 \mathrm{mg} / \mathrm{kg}$ of kolanut (group C), $2.5 \mathrm{~g} / \mathrm{kg}$ of honey (group D), honey and kolanut (group E) significantly reduced ALT, AST and ALP activities in both group $C$ and group $E$ with higher reduction in group $D$.

Table 2 and Fig. 2 showed that the administration of ethanol (45\%) at $3 \mathrm{~g} / \mathrm{kg}$ dosage significantly reduced catalase activity and increased MDA concentration when compared with the normal control (group A) at $P \otimes 0.05$ but pretreatment with $50 \mathrm{mg} / \mathrm{kg}$ of kolanut (group C), $2.5 \mathrm{~g} / \mathrm{kg}$ of honey (group D), both honey and kolanut (group E) significantly increased catalase activity and reduced MDA concentration when compared with ethanol induced group.

Table 1

Effects of aqueous extract of kolanut and honey on alanine amino transferase (ALT), aspartate amino transferase (AST) and alkaline phosphatase (ALP) activities in alcohol induced hepatoxicity in male albino rats

\begin{tabular}{|c|c|c|c|c|c|}
\hline PARAMETERS & $\begin{array}{l}\text { GROUP } \\
\text { A } \\
\text { (Control) }\end{array}$ & $\begin{array}{l}\text { GROUP B } \\
\text { (A/cohol } \\
\text { only) }\end{array}$ & $\begin{array}{l}\text { GROUP C } \\
\text { (Kolanut \& } \\
\text { Alcohol) }\end{array}$ & $\begin{array}{l}\text { GROUP D } \\
\text { (Honey \& } \\
\text { Alcohol) }\end{array}$ & $\begin{array}{l}\text { GROUPE } \\
\text { (Kolanut,Honey \& } \\
\text { Alcohol) }\end{array}$ \\
\hline ALT (U/L) & $\begin{array}{l}10.03 \pm \\
0.89\end{array}$ & $\begin{array}{l}30.92 \pm \\
0.62^{\mathrm{a}}\end{array}$ & $14.60 \pm 0.28^{a, b}$ & $12.62 \pm 1.02^{b}$ & $25.23 \pm 0.23^{a, b, c}$ \\
\hline AST (U/L) & $\begin{array}{l}63.82 \pm \\
2.25\end{array}$ & $\begin{array}{l}120.13 \pm \\
2.17^{a}\end{array}$ & $86.71 \pm 4.35^{a, b}$ & $72.11 \pm 4.00^{b}$ & $114.74 \pm 10.48^{a, c}$ \\
\hline ALP (U/L) & $\begin{array}{l}52.70 \pm \\
2.33\end{array}$ & $\begin{array}{l}124.2 \pm \\
4.36^{a}\end{array}$ & $89.24 \pm 1.80^{a, b}$ & $60.72 \pm 2.52^{b c}$ & $80.35 \pm 2.51^{a, b}$ \\
\hline
\end{tabular}

Values are expressed as mean $\pm S E M, n=6$. Values were considered significant at $P<0.05$. ${ }^{a}$ Represent significant difference when compared with normal control, ${ }^{\mathrm{b}}$ Represent significant difference when compared with ethanol-induced group, ${ }^{\mathrm{C}}$ Represent significant difference when compared with alcohol and kolanut group. 
Table 2: Effects of aqueous extract of kolanut and honey on catalase activity and malondialdehyde concentration in alcohol induced hepatoxicity in male albino rats

\begin{tabular}{|c|c|c|c|c|c|}
\hline PARAMETERS & $\begin{array}{l}\text { GROUP } \\
A \\
\text { (Control) }\end{array}$ & $\begin{array}{l}\text { GROUP } \\
B \\
\text { (Alcohol } \\
\text { only) }\end{array}$ & $\begin{array}{l}\text { GROUP C } \\
\text { (Kolanut \& } \\
\text { Alcohol) }\end{array}$ & $\begin{array}{l}\text { GROUP D } \\
\text { (Honey \& } \\
\text { Alcohol) }\end{array}$ & $\begin{array}{l}\text { GROUP E } \\
\text { (Kolanut, Honey \& } \\
\text { Alcohol) }\end{array}$ \\
\hline CAT( $\mu$ mol/minute) & $\begin{array}{l}39.4 \pm \\
1.2\end{array}$ & $\begin{array}{l}9.0 \pm \\
0.6^{a}\end{array}$ & $19.2 \pm 1.1^{\mathrm{a}, \mathrm{b}}$ & $\begin{array}{l}33.9 \pm 1.3 \\
a, b, c\end{array}$ & $21.0 \pm 0.3^{a, b}$ \\
\hline MDA(nmol/millimeter) & $\begin{array}{l}24.4 \pm \\
0.77\end{array}$ & $\begin{array}{l}37.96 \\
\pm 3.75^{a}\end{array}$ & $33.16 \pm 2.0$ & $\begin{array}{l}27.64 \pm \\
1.72^{a}\end{array}$ & $30.68 \pm 1.02$ \\
\hline
\end{tabular}

Values are expressed as mean $\pm S E M, n=6$. Values were considered significant at $P<0.05$. ${ }^{\text {a Represent }}$ significant difference when compared with normal control, ${ }^{\mathrm{b}}$ Represent significant difference when compared with ethanol-induced group, ${ }^{\mathrm{C}}$ Represent significant difference when compared with alcohol and kolanut group.

\section{Histological Analysis}

A photomicrograph of liver sections of the normal control group (group A) showed normal liver architecture, central vessels (white arrow), sinusoids (slender arrow), hepatocytes (blue arrow), no haemorrhage and there is no infiltration of inflammatory cells but a photomicrograph of liver sections of group B induced with $3 \mathrm{~g} / \mathrm{kg}$ of ethanol showed normal sinusoids (slender arrow), severe infiltration of fat within the cytoplasm of the hepatocytes (red arrow). A photomicrograph of liver sections of group $\mathrm{C}$ pretreated with $50 \mathrm{mg} / \mathrm{kg}$ of kolanut prior to administration of $3 \mathrm{~g} / \mathrm{kg}$ of ethanol showed mild perivascular infiltration (white arrow), moderately normal sinusoids (slender arrow) and fatty infiltration of the hepatocytes (red arrow). A photomicrograph of liver sections of group D pretreated with $2.5 \mathrm{~g} / \mathrm{kg}$ of honey prior to administration of $3 \mathrm{~g} / \mathrm{kg}$ of ethanol showed a normal architecture with no vascular congestion (white arrow), mild infiltration of the sinusoids by inflammatory cells (slender arrow) and normal hepatocytes (blue arrow). A photomicrograph of liver sections of group E pretreated with both $50 \mathrm{mg} / \mathrm{kg}$ of kolanut and $2.5 \mathrm{~g} / \mathrm{kg}$ of honey prior to administration of $3 \mathrm{~g} / \mathrm{kg}$ of ethanol showed congested central vessels (white arrow), hemorrhagic sinusoids with few inflammatory cell infiltration (slender arrow) and fatty infiltration of the few hepatocytes (blue arrow) when compared with normal control group.

\section{Discussion}

Hepatotoxicity resulting from exposure to harmful substances and drugs may manifest clinically or only as abnormal liver enzymes activities (Nelson and Cox, 2005). The release of liver marker enzymes such as ALT and AST into circulation indicates liver damage (Nelson and Cox, 2005; Patrick-Iwuanyanwu et al., 2011). A number of diseases such as liver damage, cancer, myopathy, testicular injury, immune 
suppression have been linked to alcohol (Ishii et al., 1997; Nelson and Cox, 2005). The result of the present study showed that the administration of ethanol (45\%) at $3 \mathrm{~g} / \mathrm{kg}$ dosage significantly increased the activities of alkaline phosphatase (ALP), alanine amino transferase (ALT) and aspartate amino transferase (AST) compared with the controls. This agrees with the result of a recent study carried out by Zhao et al. (2017). The increase in the levels of these enzyme is an indication of hepatic injury (PatrickIwuanyanwu et al., 2011; Achuba and Ogwumu, 2014; Zhao et al., 2017) following the administration of ethanol. However, pretreatment of rats with kolanut only (group C) and honey only (group D) prior to ethanol administration significantly $(P<0.05)$ reduced the activities of these liver enzymes as compared to those of the rats in ethanol only group. Zhao et al. (2017) reported that honey inhibited alcohol-induced increase in ALT and AST activities. Nonetheless, pretreatment of rats with combined kolanut and honey prior to ethanol administration significantly reduced ALT, AST and ALP activities when compared with the group given ethanol only.

Anti-oxidant enzymes such as catalase are the first line of defense against oxidative injury (Weydert and Cullen, 2010; Hou et al., 2010). Liver injury caused by ethanol is associated with increased oxidative stress and free radical-mediated tissue damage (Hou et al., 2010). There was a significant decrease in the catalase activity of rats administered with ethanol only as compared with the control group (Table 2 and Plate 1B). Decrease in the activities of antioxidant enzymes following ethanol administration has been previously reported by Shi et al. (2015) and Zhao et al. (2017). The observed decrease in the activity of catalase may have stemmed from ethanol-induced oxidative stress (Shi et al., 2017) which could deplete the antioxidant enzyme system, resulting in the decreased enzyme activity. However, pretreatment with kolanut and honey separately compared with the group administered with ethanol only had significant ( $P$ $<0.05$ ) increase in catalase activity. Similarly, catalase activity of the group pretreated with combined kolanut and honey before ethanol administration increased significantly as compared to the group administered with ethanol only. The significant $(P<0.05)$ increase in the activity of catalase in rats that were pretreated with kolanut and honey prior to ethanol administration compared with those of the rats administered with ethanol only, suggests a protective effect of kolanut and honey on ethanol-induced oxidative stress in hepatic cells. Although only honey has been reported to have prevented acute alcoholinduced liver damage (Gharzouli et al., 2002; Garciaa et al., 2015; Zhao et al., 2017), both honey and kolanut have individually been found to confer protection against free radical-induced damage via their anti-oxidant properties (Alvarez-Suarez et al., 2010; Garciaa et al., 2015; Zhao et al., 2017). The liver contains an ample amount of oxidizable substances and this makes it highly susceptible to preoxidative damage (Nelson and Cox, 2005). The value of MDA (Malonyldialdehyde) in rats administered with ethanol $(45 \%)$ at $3 \mathrm{~g} / \mathrm{kg}$ dose significantly increased $(P<0.05)$ compared with the controls. This collaborates the results of Shi et al. (2015) and Zhao et al. (2017) who reported significant increased MDA concentration upon ethanol administration in rats. The observed significant increase in MDA concentration may have stemmed from ethanol-mediated peroxidation of lipids as the free radicals generated from ethanol metabolism would have reacted rapidly with lipids, thereby leading to lipid peroxidation (Shi et al., 2015). Pretreatment of rats with kolanut alone did not significantly $(P<0.05)$ reduced the MDA concentration meanwhile, honey alone and kolanut and honey significantly reduced the 
MDA concentration (Table 1\& Plate 1). Whereas Shi et al. (2015) found no correlation between honey pretreatment of rats intoxicated with alcohol and significant reduction in MDA concentration, Zhao et al. (2017) reported that $A$. cerana honey significantly $(\mathrm{P}<0.05)$ reduced hepatic MDA production in model rats. Since increased MDA production is one of the consequences of free radical generation, the significant reduction in MDA concentration observed in this study may have been the result of the scavenging activity of free radicals by the antioxidants present in honey (Farombi, 2000; Ujowundu et al., 2011). Furthermore, combined pretreatment with kolanut and honey did not as expected, show higher potency in reducing liver damage compared with honey alone group. Moreover, the powerful effect of honey against alcohol-induced hepatotoxicity observed in this study can be attributed to its potent antioxidant property and the effect of fructose or glucose on alcohol absorption and metabolism. Dietary fructose or glucose supplementation has been reported to enhance alcohol elimination and inhibit some metabolic alterations induced by ethanol in hangover male volunteers (Ylikahri et al., 1976; Shi et al., 2015).

Histopathological analysis of the liver of the experimental rats depicted a case of severe alcohol induced micro steatosis with severe infiltration of fat within the cytoplasms of hepatocytes (Plate 1B) in rats administered with ethanol only. Plate $1 \mathrm{C}$ shows a case of moderate alcohol-induced micro steatosis in rats pretreated with kolanut prior to ethanol administration. This further indicates that kolanut has a protective effect on ethanol-induced liver damage. Plate 1D depicts the liver of rats pretreated with honey only prior to alcohol administration. The liver architecture is normal and there is neither any case of alcohol-induced micro steatosis nor infiltration of fat cells except that there is mild lymphocyte aggregate and mild infiltration of inflammatory cells when compared with the control. The high potency of honey in ameliorating hepatotoxicity caused by alcohol and other chemicals or drugs has severally been reported (Gharzouli et al., 2002; Achuba and Nwaokoba, 2015; Garciaa et al., 2015; Zhao et al., 2017). In Group E, the combined pretreatment of rats with kolanut and honey prior to ethanol administration caused significant reduction in the damage caused by alcohol. However there was a mild case of alcohol-induced micro steatosis seen in the group pretreated with both honey and alcohol.

\section{Conclusion}

From the results of our present study, it is interesting to note the following. Firstly, honey has a much greater protective potency against ethanol-induced hepatotoxicity than kolanut. Secondly, the protective effect of honey surpasses that of combined pretreatment with kolanut and honey. Thirdly, the combined pretreatment of rats with kolanut and honey produced a greater protection than pretreatment with kolanut only. It can be concluded that both honey and kolanut has the ability to protect the liver against ethanolinduced injuries. Moreover, honey has proved to be more effective than kolanut and the observed reduced protective effect of combining kolanut and honey as compared to honey alone, may be attributed to the inhibition of glucose or fructose catabolizing enzymes by caffeine present in kolanut since the ability of honey to protect the liver against ethanol-induced injuries is connected with the effect of fructose and/ or glucose in honey on the absorption, elimination and metabolism of ethanol. 


\section{Declarations}

\section{Ethics approval}

All animals used were approved by the Animal usage committee of Ladoke Akintola University of

Technology Animal Care and Ethics Committee

\section{Consent for publication}

Not applicable

\section{Availability of data and materials}

The datasets during and/or analysed during the current study available from the corresponding author on reasonable request.

\section{Competing interests}

The authors declare that they have no competing interests" in this section.

\section{Funding}

The Authors of the Article contributed equally for the funding of the Research.

\section{Authors' contributions}

Conception: [Saka Waheed Adeoye, ${ }^{2}$ Kehinde Busuyi David, ${ }^{3}$ Akintola Adebola Olayemi ${ }^{*},{ }^{1}$ Oyekanmi Seyi Samuel, ${ }^{3}$ Oyewande Esther Ajoke, ${ }^{4}$ Murphy Dumbiri Ogwumu.]

Design: [Saka Waheed Adeoye, ${ }^{2}$ Kehinde Busuyi David, ${ }^{3}$ Akintola Adebola Olayemi ${ }^{\star},{ }^{1}$ Oyekanmi Seyi Samuel, ${ }^{3}$ Oyewande Esther Ajoke, ${ }^{4}$ Murphy Dumbiri Ogwumu.]

Execution: [Saka Waheed Adeoye, ${ }^{2}$ Kehinde Busuyi David, ${ }^{3}$ Akintola Adebola Olayemi* ${ }^{1}$ Oyekanmi Seyi Samuel, ${ }^{3}$ Oyewande Esther Ajoke, ${ }^{4}$ Murphy Dumbiri Ogwumu.]

Interpretation: [Saka Waheed Adeoye, ${ }^{2}$ Kehinde Busuyi David, ${ }^{3}$ Akintola Adebola Olayemi ${ }^{\star},{ }^{1}$ Oyekanmi Seyi Samuel, ${ }^{3}$ Oyewande Esther Ajoke, ${ }^{4}$ Murphy Dumbiri Ogwumu.]

Writing the paper: [Saka Waheed Adeoye, ${ }^{2}$ Kehinde Busuyi David, ${ }^{3}$ Akintola Adebola Olayemi* ${ }^{1}$ Oyekanmi Seyi Samuel, ${ }^{3}$ Oyewande Esther Ajoke, ${ }^{4}$ Murphy Dumbiri Ogwumu.]

\section{ACKNOWLEDGEMENT}

The authors wish to appreciate the support of Dr. Peter Otegbade of The Multidisciplinary Central Research Laboratory (MCRL) of the University of Ibadan for assistance rendered during the Research 


\section{References}

1. Achuba, F. I., and Nwokoba, C. C. (2015). Effects of honey supplemention on hydrocarbon-induced kidney and liver damage in wistar albino rats. Biochemistri, 27,50-55.

2. Achuba, F. I., and Ogwumu, M.D. (2014). Possible protective role of palm oil and beef liver on the kidney and liver of wistar albino rats fed diesel-contaminated diet. Biokemistri, 26, 124-129.

3. Aebi, H.E. (1983). Catalase. In: Bergmeyer, H.U., Ed., Methods of Enzymatic Analysis, VerlagChemie, Weinhem, 273- 286.

4. Ajibola, A., Chamunorwa, J. P., and Erlwanger, K. H. (2012)Nutraceutical values of natural honey and its contribution to human health and wealth. Nutrition and Metabolism, 9(61)1186/1743-7075-9-61.

5. Alvarez-Suarez, J. M., Tulipani, S., Diaz, D., Estevez, Y., Romandini, S., Giampieri, F., Damiani, E., Astolfi, P., Bompadre, S., and Battino, M. (2010). Antioxidant and antimicrobial capacity of several monofloral Cuban honeys and their correlation with color, polyphenol content and other chemical compounds. Food and Chemical Toxicology, 48, 2490-2499.

6. Amadei, S. U., Souza, D. M., Brandao, A. A. H., and Rocha, R. F. (2011). The influence of different durations of estrogen deficiency on alveolar bone loss in rats.Brazilian Oral Respiration, 25, 538-543.

7. Ayebe, E. K., Yapi, H. F.,Edjeme, A. A. et al., (2012)."In vivo, in vitro antioxidant activity assessment and acute toxicity of aqueous extract of Cola nitida (Sterculiaceae). Asian Journal of Biochemical and Pharmaceutical Research, 2(4), 144-155.

8. Brabant, C., Guarnieri, D. J., and Quertemont, E. (2014). Stimulant and motivational effects of alcohol: lessons from rodent and primate models. Pharmacology, Biochemistry and Behavior, 122C, 37-52.

9. Chepulis, L. M. (2007).The effects of honey compared with sucrose and a sugar-free diet on neutrophil phagocytosis and lymphocyte numbers after long-term feeding in rats. Journal of Complementand Integrated Medicine,4, 1-7.

10. Christophersen, C., Larsen, C., and Dimayuga, R.E. (1991).Traditional Medicine-A Potential Resource Exploitation of Natural Products. The H.C. Orsted Institute, Copenhagen, Denmark, pp: 8-12.

11. Dah-Nouvlessounon, D., Adoukonou-Sagbadja, H., Diarrassouba, N., Sina, H., Adjanohoun, A., Inoussa, M.,Akakpo, D., Gbenou, J. D., n O. Kotchoni, S. O., Dicko, M. H., and Baba-Moussa, L. (2015). Phytochemical Analysis and Biological Activities of Cola nitida Biochemistry Research International, 2015, 493879, 12.https://doi.org/10.1155/2015/493879.

12. Dewole, E.A., Dewumi, D.F.A., Alabi, J.Y.T., and Adegoke, A. (2013). Proximate and Phytochemical of Cola nitida and Cola acuminata. Pakistan Journal of Biological Sciences, 16,1593-1596.

13. Eliasson, E., and Johansson, I. (1988). Ligand-dependent maintenance of ethanol- inducible cytochrome P-450 in primary rat hepatocyte cell cultures. Biochemical and Biophysical Research Communications, 150(1), 436-43.

14. Farombi, E.O. (2000). Mechanisms for the hepatoprotective action of kolaviron, studies on hepatic enzymes, microsomal lipids and peroxidation in carbon tetrachloride-treated rats. Pharmacological 
Research, 42, 75-80.

15. Garcia, J. A. D., Souza, A. L. T., Cruz, L. H. C., Marques, P. P., Camilli, J. A., Nakagaki, W. R., Esteves, A., Rossi-Junior, W. C. , Fernandes, G. J. M., Guerra, F. D., and Soares, A.(2015). Effects of ethanol consumption and alcohol detoxification on the biomechanics and morphology of the bone in rat femurs. Brazilian Journal of Biology Chemistry, 75(4), 983-988.

16. Gharzouli, K., Amira, S., Gharzouli, A., and Khennouf, S. (2002). Gastro protective effects of honey and glucose-fructose-sucrose-maltose mixture against ethanol-, indomethacin-, and acidified aspirin induced lesions in the rat. Experimental Toxicology and Pathology, 54, 217-221.

17. Hendler, R. A., Ramchandani, V. A., Gilman, J., and Hommer, D. W. (2013). Stimulant and sedative effectsof alcohol. Current Topics in Behavioral Neuroscience, 13, 489-509.

18. Hou, Z. H., Qin, P. Y., and Ren, G. X. (2010). Effect of anthocyanin-rich extract from black rice (Oryza sativa Japonica) on chronically alcohol-induced liver damage in rats. Journal of Agriculture and Food Chemical, 58, 3191-3196.

19. Ishii, T., and Itoh, K. (2000). Transcription factor Nrf2 coordinately regulates a group of oxidative stress-inducible genes in macrophages. Journal of Biological Chemistry, 275(21), 16023-16029.

20. Javies, G. (2002). The rise and fall of cocaine cola,http://www.unz.org/Pub/LewRockwell 2002may00039.

21. Karlsson, O., and Roman, E. (2016).Dose-dependent effects of alcohol administration on behavioralprofiles in the MCSF test. Alcohol, 50, 51- 56.

22. Keegan, A., and Batey, R.(1993). Dietary carbohydrate accelerates ethanol elimination, but does not alter hepatic alcohol dehydrogenase. Alcohol, Clinical and Experimental Research, 17, 431-433.

23. Lieber, C. S. (1988). The microsomal ethanol oxidizing system: its role in ethanol and xenobiotic metabolism. Biochemical Society Transactions, 16(3), 232-9.

24. Lowenstein, L. M., Simone, R., Boulter, P.,and Nathan, P. (1970). Effect of Fructose on Alcohol Concentrations in the Blood in Man. JAMA, 213:1899-1901.

25. Lowor, S. T.,Aculey, P. C., andAssuah, M. K. (2010).Analysis of some quality indicators in cured Cola nitida (Vent).Agriculture and Biology Journal of North America, 1(6), 1206-1214.

26. Marczinski, C. A., Fillmore, M.T. (2014). Energy drinks mixed with alcohol: what are the risks? Nutritional Review, 72(suppl 1), 98-107.

27. Molan, P. (1999).Why honey is effective as a medicine.It's use in Modern medicine. Bee World, 80,7992.

28. Muhammad, S., and Fatima, A. (2014).Studies on phytochemical evaluation and antibacterial properties of two varieties of kolanut (Cola nitida) in Nigeria. Journal of Biosciences andMedicines, 2(3),37-42.

29. Nasuti, C., Gabbianelli, R., Falcioni, G., and Cantalamessa, F.(2006).Antioxidative and gastro protective activities of anti-inflammatory formulations derived from chestnut honey in rats. Nutritional Research, 26,130-137. 
30. Nelson, D. L., Cox, M. M. (2005). Lehninger's Principles of Biochemistry (4th Ed.), WH Freeman \& Co,New York.

31. Nwaogu, L.A ., and Onyeze, G.O. (2014).Effect of chronic exposure to petroleum hydrocarbon pollution on oxidative stress parameters and histology of liver tissues of native fowl (Gallus domestics).International Journal of Biochemistry Research and Reviews, 4, 233-242.

32. Onyesom, I., and Anosike, E. O. (2004). Oral fructose-induced changes in blood ethanol oxidokinetic data among healthy Nigerians. Southeast Asian Journal of TropicalMedicine and Public Health, $35,476-480$.

33. Patrick-Iwuanyanwu, K.C.,Onyemaenu, C.C., Wegwu, M.O, and Ayalogu, E.O. (2011).Hapatotoxic and Nephrotoxic Effect of kerosene and gasoline-contaminated Diet in the Wistar Albino Rats.Research Journal of Environmental Toxicology, 5, 49-57.

34. Portari, G. V., Marchini, S., Vannucchi, H., and Jordao, A. A. (2008). Antioxidant effect of thiamine on acutely alcoholized rats and lack of efficacy using thiamine or glucose to reduce blood alcohol content. Basic Clinical Pharmacology and Toxicology,103,482-486.

35. Raeessi, M. A.,Raeessi, N., Panahi, Y., Gharaie, H.,Davoudi, S. M., Saadat, A., Zarchi, A. A. K., Raeessi, F., Ahmadi, S. M., and Jalalian, H. (2014). "Coffee plus honey" versus 'tropical steroid" in the treatment of chemotherapy-induced oral mucositis: arsndomised controlled trial. BMC Complement and Alternative Medicine,14: 293.

36. Root, A.I., and Root, E.R. (2005). The abc and xyz of bee culture. Kessinger Publishing. Whitefish.

37. Schukit, M. A., Smith, T. L., and Kalmijn, J. (2004). The search for genes contributing to the low level of response to alcohol: patterns of findings across studies. Alcoholism: Clinical andExperimental Research, 28, 1449-1458.

38. Shadkam, M. N., Mozaffari-Khosravi,H.,andMozayan,M.R. A. (2010).Comparison of the effect of honey, dextromethorphan, and diphenhydramine on nightly cough and sleep quality in children and their parents. Journal of Alternative and Complement Medicine, 16(7),787-793.

39. Shi, P., Chen, B., Chen, C., Xu, J., Shen, Z., Miao, X., and Yao, H. ( 2015). Honey reduces blood alcohol concentration but not affects the level of serum MDA and GSH-Px activity in intoxicated male mice models. BMC Complement and Alternative Medicine, 15, 225-231.

40. Sofowora, A. (1993). Medicinal Plants and Traditional Medicine in Africa.Spectrum Books Limited, Sunshine House, Ibadan, Nigeria, 2nd edition.

41. Souza, D. M., Silva, A. A., Pereire, K. A., Gonsalves, V. S., and Rodrigues, V. A. (2017).Alveolar bone loss induced by alcohol consumption in rats. Brazilian Dental Science, 20(4), 42-48.

42. Spanagel, R. (2009). Alcoholism: a systems approach from molecular physiology to addictive behavior. Physiological Reviews, 89, 649-705.

43. Tortora, P., Burlini, N., Hanozet, G. M., and Guerritore, A. (1982). Effect of caffeine on glucose-induced inactivation of gluconeogenetic enzymes in Saccharomyces cerevisiae.A possible role of cyclic AMP.European Journal of Biochemistry, 126(3),617-22. 
44. Ujowundu, C.O., Kalu, F. N., Igwe,C.U., Agha, N. C., and Igwe, K. O. (2012) Biochemical studies on the amelioration of petroleum product intoxication with indigenous plants. International Journal of Biochemistry Research and Review, 2, 87-97.

45. Van Wyk, B.E.,and N. Gericke, 2000.People's Plants: A Guide to Useful Plants of Southern Africa. Briza Publications, Pretoria, South Africa, ISBN-13: 9781875093199 , Pages: 351.

Weydert, C., and Cullen J. J. (2010).Measurement of superoxide dismutase, catalase, and glutathione peroxidase in cultured cells and tissue. National Protoc, 5(1), 51-66.

46. World Health Organization.Global status report on alcohol and health. 2014. Geneva (http://apps.who.int/iris/bitstream/10665/112736/1/9789240692763_eng.pdf).

47. Ylikahri, R. H., Leino, T., Huttunen, M. O., Pösoö, A. R., Eriksson, C. J. P., andNikkilä, E. A. (1976).Effects of fructose and glucose on ethanol-induced metabolic changes and on the intensity of alcohol intoxication and hangover. European Journal of Clinical Investigation, 6, 93-102.

48. Zhao, H., Cheng, N., He, L., Peng, G., Xue, X., Wu, L., and Cao, W. (2017).Antioxidant and hepatoprotective effects of cerana honey against acute alcohol-induced liver damage in mice. Food Research International, 101, 35-44.

\section{Figures}

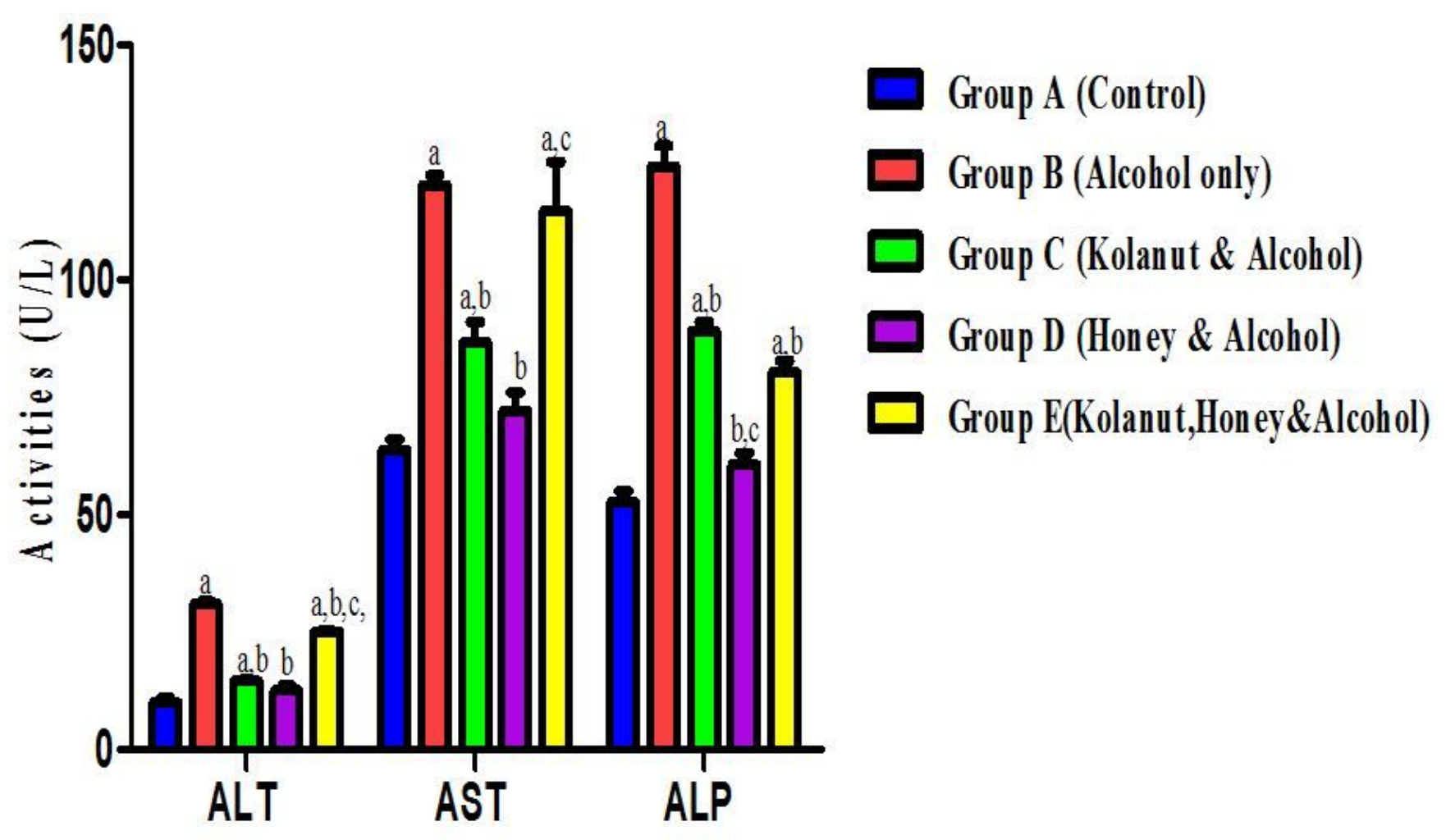

Figure 1 


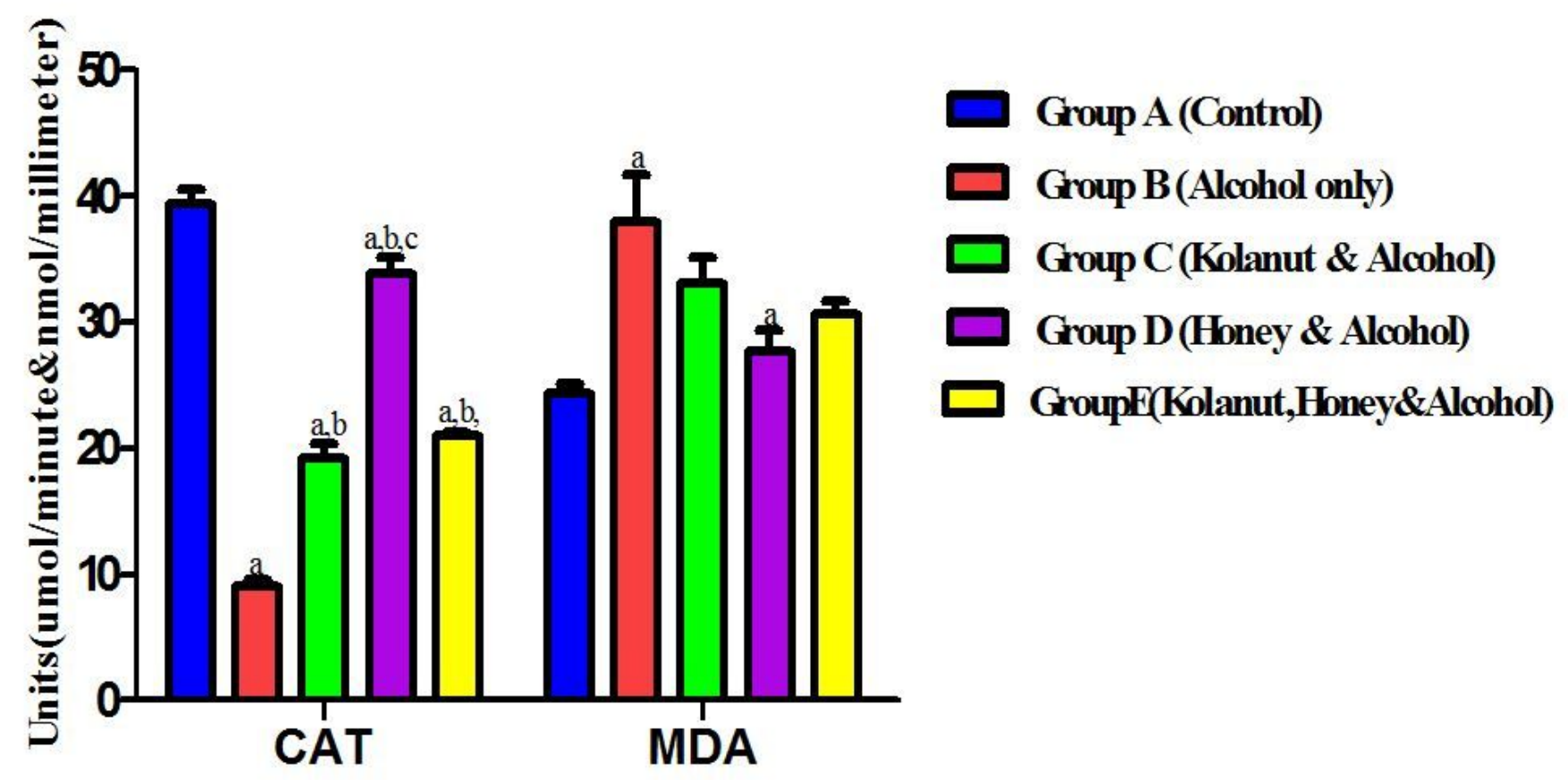

Figure 2

Effects of aqueous extract of kolanut and honey on catalase activity and malondialdehyde concentration in alcohol induced hepatoxicity in male albino rats. 